\title{
Separate but not Equal: The Supreme Court's First Decision on Racial Discrimination in Schools
}

\author{
By J. Morgan Kousser
}

IN 1899, THREE YEARS AFTER THE "SEPARATE BUT EQUAL" DECIsion of Plessy v. Ferguson, the U. S. Supreme Court for the first time confronted the problem of racial discrimination in education. Writing for a unanimous court, Justice John Marshall Harlan, whose recently refurbished reputation rests chiefly on his liberal opinions in Negro rights cases, decided in effect that the judiciary would do no more to guarantee equality in public services than it had to stop legalized segregation. ". . . the education of the people in schools maintained by state taxation is a matter belonging to the respective States, " the justice, who was rarely a protector of states' rights, concluded, "and any interference on the part of Federal authority with the management of such schools cannot be justified except in the case of a clear and unmistakable disregard of rights secured by the supreme law of the land. We have here no such case to be determined ...." Attracting even less attention at the time than Plessy did, the case of Joseph W. Cumming, James S. Harper, and John C. Ladeveze v. School Board of Richmond County, Ga. has never received the attention Plessy gained in the wake of the outlawing of segregation in the 1954 Brown decision.2 The leading

175 U.S. 528, 545. On Harlan's reputation and the reasons for changes in it see $\mathbf{G}$. Edward White, The American Judicial Tradition: Profiles of Leading American Judges (New York, 1976), 129. Research for this paper was partially supported by the Arnold L. and Lois S. Graves Award and by research funds from the Division of Humanities and Social Sciences at California Institute of Technology. I owe a great deal of thanks to several people who provided me with information and leads to further information: Professor Edward J. Cashin of Augusta College, Mr. Joseph B. Cumming, Mrs. Virginia de Treville of the Augusta College Library, and especially Mrs. Mary Harper Ingram; and to colleagues who were kind enough to comment on an earlier version of the paper, Robert F. Engs, Clayton $R$. Koppes, and Stanley N. Kutler.

2 According to Raymond P. Stone Plessy v. Ferguson, 163 U.S. 537 (1896) "went virtually unnoticed"' in newspapers and legal journals at the time, attracting less attention in most of the newspapers which regularly covered the Court's decisions than an obscure civil case MR. KousSer is professor of history at the California Institute of Technology.

The Journal of Southern History

Vol. XLVI, No. 1, February 1980 
case on educational discrimination for four decades, Cumming has neither been specifically overruled by judges nor subjected to more than passing mention by legal scholars or historians. ${ }^{3} \mathrm{~A}$ thorough analysis of the Cumming case will cast new light on the nature of race relations, racial politics, and the character of the black elite in the postbellum South; raise serious questions about Justice Harlan's devotion to civil rights; and contribute to the growing tenI he this clew dency to substitute a broader social history for the narrow study of if secems to imply a ixve tu reen abstract legalistic principles which has until recently constituted the history of law. ${ }^{4}$

between the Four factors shaped the course of black education in Augusta and mind prousses the surrounding county of Richmond in the late nineteenth century: profession and the black masses' strong desire for education, black political power, thatef a rasis the activities of the black elite, and the attitudes of white leaders. Denied an education, at least in law, before 1865, the former slaves and free people of color developed "an almost limitless faith in the possibilities of advancement through schooling."' As early as June 1866 the blacks' push to learn led the local Inferior Court, which served at the time as Augusta's school board, to hold a public meeting to offer local financial support for a few schools for Negroes until the legislature could set up a formal state-funded system. At

decided the same day. The New York Times briefly summarized Plessy in a column headlined "Railway News," and the Washington Post, noting that carpetbagger-lawyer-novelist Albion Winegar Tourgete had represented Plessy, curtly dismissed the case as "another fool's errand," a reference to Tourgée's most famous novel. See Stone, " 'Separate But Equal": The Evolution and Demise of a Constitutional Doctrine"' (unpublished Ph.D. dissertation, Princeton University, 1964), 263-64. There are brief newspaper reports on Cumming in Washington Post, December 19, 1899, p. 5; Cleveland Gazette, December 30, 1899; Philadelphia Public Ledger, December 19, 1899, p. 12; and, of course, longer treatments in the Georgia newspapers. The best of the numberless treatments of Plessy are C. Vann Woodward, American Counterpoint: Slavery and Racism in the North-South Dialogue (Boston and Toronto, 1971), 212-33; and Otto H. Olsen, ed., The Thin Disguise: Turning Point in Negro History, Plessy v. Ferguson ... (New York, 1967). See pp. 25-27, 123-30, of Olsen's book for another treatment of the response to Plessy.

3 The National Association for the Advancement of Colored People (NAACP) and the Court majority tiptoed around Cumming, much to the dissenters' disgust, in Missouriex. rel. Gaines v. Canada, 305 U.S. 337, 340, 353 (1938), and lawyers for both sides in Brown handled the by then doddering Cumming precedent gingerly. See Leon Friedman, ed., Argument: The Oral Argument Before the Supreme Court in Brown v. Board of Education .. . (New York, 1969), 42n, 57, 231: Brown v. Board of Education, 347 U.S. 483, 491 (1954). Most of the treatments of the case devote only one or two paragraphs to it. For specific citations see below, notes 47-48, 53-56.

4 For a variety of attempts to escape the coils of narrow constitutional doctrine as the exclusive focus of legal history see Wythe Holt, ed., Essays in 19th Century American Legal History (Westport, Conn., 1976); and Richard Kluger, Simple Justice (New York, 1975).

s John M. Matthews, "Studies in Race Relations in Georgia, 1890-1930," (unpublished Ph.D. dissertation, Duke University, 1970), 9. The 1829 law making it illegal to teach any black to read or write seems to have been widely ignored. See Edward F. Sweat, "The Free Negro in Ante-Bellum Georgia"' (unpublished Ph.D. dissertation, Indiana University, 1957), 205-207. 
the urging of spokesman Robert Augustus Harper, the blacks at the meeting agreed to accept the court's proposal as a gesture of good faith., Though it is unclear from surviving records whether the whites followed through completely on their promise, the fact that they gave it does indicate a desire on their part to conciliate the blacks or at least to keep control of the Negroes' education in the hands of the southern whites. ${ }^{6}$ But since the 1866 Johnsonian legislature confined fiscal support to white schools and the turbulence of Congressional Reconstruction in Georgia prevented the establishment of a stable state educational system, schooling for Augusta blacks in the 1860s and early 1870 s depended entirely on the efforts of the local community, the Freedmen's Bureau, and northern missionary societies. ${ }^{7}$ Only after the Democrats regained control of Georgia in 1871 and 1872 was the biracial public school system put on a firm footing in Richmond County.

Black political power left its impress on the state legislature's 1872 passage of a bill, drawn up by a local committee of nineteen whites, which established a countywide system of education in Richmond County and granted its school board extraordinary powers. ${ }^{8}$ Section 9 of the bill, though mandating segregation, specifically provided that the Richmond County School Board "shall provide the same facilities for both [white and Negro children], both as regards schoolhouses and fixtures, attainments and abilities of teachers, length of term time, and all other matters appertaining to education . . . ." Unlike most other school boards in Georgia, the Richmond County board could establish high schools (Section 10) and levy local taxes without a referendum, and no general law on education could supersede the 1872 special act. Furthermore, Richmond County was expressly excused from the 1877 state constitution's prohibition on public high schools.'

Their rights guaranteed in law, black leaders pressed for full im-

\footnotetext{
- Augusta Chronicle, July 1, 1866. The Augusta Daily Press, May 3, June 21, 1866, quoted in Alan Conway, The Reconstruction of Georgia (Minneapolis, 1966), 86, favored setting up schools for blacks by southern whites to preempt northerners from control.

' On the bureau schools see Conway, Reconstruction, 84-96. The local school board did partially subsidize the salaries of bureau teachers in Augusta. See Jacqueline Jones, "The 'Great Opportunity': Northern Teachers and the Georgia Freedman, 1865-1873" (unpublished Ph.D. dissertation, University of Wisconsin, 1976), 403.

- The fact that it was drafted locally implies that the law reflected the opinion of the Augusta white elite, at least, and not simply that of a legislative committee. On the writing of the bill see Augusta Chronicle, May 21, 24, 1872. For the act see Public Law 456, Georgia, Public Laws Passed by the General Assembly . . . 1872 (Atlanta, 1872).

- See Article VIII, Section V, Paragraph I, of the 1877 constitution, Francis N. Thorpe, comp., The Federal and State Constitutions . . . (7 vols., Washington D. C., 1909), II, 868. The board was allowed, if it wished, to charge tuition in high schools by Section 10, Public Law 347 of 1877.
} 
plementation by the board. Pointing out that the buildings allocated to blacks could not accommodate all those who sought admission during the 1872-1873 term, former Freedmen's Bureau agent William Jefferson White offered the Richmond County School Board three buildings which had been owned by the bureau and two rooms in the black Harmony Baptist Church, of which he was pastor. ${ }^{10}$ Stressing both student demand and the need to train teachers for the elementary schools, White also petitioned for a black public high school. In response, the city's leading newspaper noted the provisions of the law and endorsed White's request as "just and fair." "If the whites have high schools, grammar, intermediate and primary schools," the Chronicle's editorial continued, "let the colored children have them also. Let no children, white or colored, be turned away for want of teachers, or school room, or books, whose parents or guardians are desirous that they should receive an education. Give both races exactly the same opportunities and equal advantages."'11

Described by the Negro Atlanta Age as "the father of [Negro] education" in Georgia, White had started Augusta Baptist Institute, which later became Morehouse College, in 1867. Originally devoted to upgrading the meager educational attainments of black Baptist ministers, the institute seems to have functioned primarily as a high school for the black community during the 1870s. When its trustees decided in 1879 that a move to Atlanta would put the school on a firmer financial footing, the long-delayed issue of a public high school for blacks came to a head.12

Richmond County in 1880 supported one semipublic and two public high schools for whites and from time to time had partially subsidized the venerable Academy of Richmond County for boys. ${ }^{13}$ It was, therefore, obvious to county school commissioner William Henry Fleming that the 1872 law required the school board to take

10 Augusta Chronicle, April 13, 1873.

"Ibid., July 22, 1873.

12 Atlanta Age, quoted in Savannah Tribune, April 30, 1898; John A. Dittmer, "The Black Man and White Supremacy in Georgia During the Progressive Era" (unpublished Ph.D. dissertation, Indiana University, 1971), 183; Mrs. Mary Blocker (daughter of William J. White) to Laura Harper, April 8, 1962, in a collection of papers now in possession of Mrs. Mary Harper Ingram of Atlanta, which will be referred to hereinafter as Harper Family Papers; Ridgely Torrence, The Story of John Hope (New York, 1948), 122; Willard Range, The Rise and Progress of Negro Colleges in Georgia, 1865-1949 (Athens, Ga, 1951), 8, 16, 24-26, 53, 108; Benjamin G. Brawley, History of Morehouse College (Atlanta, Ga., 1917), $12-27$

is The mix of public and private funding and the charging of tuition in "public" high schools was quite typical of the pragmatic, unbureaucratized school systems of the South during this period. See John L. Maxwell, Pleasant A. Stovall, and T. R. Gibson, The Handbook of A ugusta (Augusta, 1878), 63-66; Augusta Chronicle, June 18-21, September 18-20, 1895; February 12, 1900. 
positive action on a July 1880 petition requesting a black public high school. Appointed at a mass meeting of the black population, the committee of five leading Negroes, which included William J. White, Robert Harper's son James S. Harper, and Colored Methodist bishop Lucius Henry Holsey, "respectfully but earnestly" called for compliance with the law. In response, Fleming, an outspoken racial moderate whose views did not prevent his later election as speaker of the state House of Representatives and as congressman from Augusta, reminded the board of Section 9 of the 1872 law and reiterated his previous recommendation in favor of a black high school. "To grant to-day the petition of the colored people," Fleming announced, "would be only an act of tardy justice."'14

Asserting that the law compelled the establishment of a black high school eventually but not immediately, the lawyer for the board and chairman of its high school committee, Joseph Ganahl, moved successfully to "accept" rather than "adopt" Fleming's report, and it appeared that the board would bury the blacks' petition in committee. Between the July and October board meetings, however, the issue of black schools agitated both state and national elections. Reminding his audience at a political rally that black as well as white taxes supported the white high schools, 1880 Republican national convention delegate and former state legislator Edwin Belcher condemned the board: "The school law says equal facilities shall be given white and colored children. Now the white children have a high school and the colored have none. . . . That will not do."15 The Eighth Congressional District Republican Convention, moreover, heard William J. White's denunciation of "the discrimination against colored children and colored teachers in many of the counties of the State." And in the hotly contested gubernational race between Alfred Holt Colquitt and Thomas Manson Norwood, the young Thomas Edward "Tom" Watson claimed in an

\footnotetext{
14 On the black petition and meeting see "Minutes of the Richmond County School Board, 1876-1891," 132-33, bound manuscript, in the school board offices, Augusta, hereinafter referred to as "Minutes." On Fleming see Edward L. Cashin, "Thomas E. Watson and the Catholic Laymen's Association of Georgia" (unpublished Ph.D. dissertation, Fordham University, 1962), 13, 59-61, 91-92; Augusta Chronicle, July 11, 1880 (quotation); May 13, June 5, 6, 1902; June 20, 22, 1906; Fleming, Slavery and the Race Problem in the South (Boston, [1906]). For further information and more complete citations of sources of information on Fleming and other Augustans treated in this paper, see my "Separate but Not Equal: The Supreme Court's First Decision on Discrimination in Schools," unpublished California Institute of Technology Working Paper, No. 204 (March 1978).

1s On the board meeting see Augusta Chronicle, July 11, October 10, 1880; Ganahl's motion is in "Minutes" (1876-91), 126-27. Belcher's speech is in Augusta Chronicle, July 28,1880 . On Belcher, a light-skinned Negro who was a forceful proponent of black political power, see Edward E. Young, "The Negro in Georgia Politics, 1867-1877" (unpublished M.A. thesis, Emory University, 1955), 35; Olive H. Shadgett, The Republican Party in Georgia from Reconstruction Through 1900 (Athens, Ga., 1964), 78-79.
} 
Augusta speech that blacks should support Norwood because he would give them "a fair share in education." Because there was no registration law and the poll-tax prerequisite was seldom strictly enforced (an 1881 grand jury investigation showed that only 30 percent of the voters in the 1880 municipal election had paid their taxes), the blacks voted freely in local as well as state and national elections, and, according to the Chronicle, "their votes were sought by all the candidates," Democrats as well as Republicans. Perhaps responding to the pressure of the black electorate, the school board at its October 1880 meeting voted to establish a black high school, overriding the objection of one board member that the shortage of places in black primary schools should be alleviated before allocating money to the higher branches. ${ }^{16}$

The black community demonstrated its control over its own schools immediately, as William $\mathrm{J}$. White was allowed to recruit perhaps the best-qualified black teacher in the state as the high school's principal-teacher. Born a slave in 1855, the new principal, Atlanta University graduate Richard Robert Wright, quickly gained the respect of the local black leadership as well as the white school board. ${ }^{17}$ As if to underline the independence of the high school from southern white control, Wright named it for his mentor, the Massachusetts-born white carpetbagger and Freedmen's Bureau officer who founded and served as president of the then highly controversial Atlanta University, Edmund Asa Ware. ${ }^{18}$

Ware High, which offered the same classical curriculum as the white schools, quickly became a "complete success" in the words of 1881 county school commissioner Benjamin Neely. It was the only public high school for Negroes in Georgia before 1915 and one of perhaps four in the eleven ex-Confederate states in 1880. Providing

1. The quotations are taken, respectively, from the Augusta Chronicle, September 2, October 2, and July 22, 1880. The grand jury investigation was reported in Augusta Chronicle, October 30,1881. Supported by other state black leaders, Colquitt carried the black vote in Augusta, 780 to 133. Augusta Chronicle, October 7, 1880. On black participation in Augusta politics during this period see William B. Hamilton, "Political Control in a Southern City: Augusta, Georgia, in the 1890s" (unpublished A.B. thesis, Harvard University, 1972), 34-54; Richard H. L. German, "The Queen City of the Savannah: Augusta, Georgia, During the Urban Progressive Era, 1890-1917”' (unpublished Ph.D. dissertation, University of Florida, 1971), 46, 152. Until about 1900 black votes bought lenient enforcement of the law for Augusta Negroes according to A. G. Coombs and L. D. Davis, "Crime in Augusta," in W. E. Burghardt Du Bois, ed., Some Notes on Negro Crime, Particularly in Georgia 'Atlanta, Ga., 1904), 52-53.

17 Elizabeth R. Haynes, The Black Boy of Atlanta (Boston, 1952), 99-101, 120, and passim; and Clarence A. Bacote, "The Negro in Georgia Politics, 1880-1908" (unpublished Ph.D. dissertation, University of Chicago, 1955), 52-53, 236; Shadgett, Republican Party, 84-85; Augusta Chronicle, April 16, 1881; June 9, July 2, 8, 1897.

10 On Ware see National Cyclopedia of American Biography, V (New York, 1907), 380. On integrationist Atlanta University see Range, Rise and Progress of Negro Colleges, 60-63. 
comparatively well-trained teachers for Richmond and the surrounding counties, the school served as well as a source of pride and an avenue of mobility for Augusta's energetic, striving black community. ${ }^{19}$ Although sectarian pride and the insatiable black demand for education led the Baptists, Methodists, and Presbyterians to open separate black high schools in Augusta over the next dozen years (at least one of which unsuccessfully petitioned for a subsidy from the school board) Ware remained, according to the Chronicle, "the leading high school among the colored people of this state." 20

Ware High served political as well as educational purposes. Straining for every vote in his three congressional contests with the Populist Tom Watson, Democrat James Conquest Cross Black appealed for Negro votes in Augusta on the ground that in Richmond County, "the colored girls and colored boys are educated at the expense of the whites and given the benefits not only of a common school, but a high school education." The $\$ 800$ yearly net expense of Ware High was, so long as Negroes voted, a good investment for the Democrats. In response to Black, Watson claimed that Negroes paid approximately as much through direct and indirect taxes as they received for schools. The Populists, Watson asserted, would allocate to Negroes their "share of the public school fund" on grounds of simple justice, without the Democrats' "misleading" and specious pretensions to paternalism. ${ }^{21}$

In fact, the Democratic claims were exaggerated, for Augusta's black schools were by no means equal to those for whites. Housed in

19 "Minutes" (1876-91), 153, for Neely's statement; 13th Annual Report of the Public Schools of Richmond County, 1885 (Augusta, 1886), 15-16; German, "Queen City," 36-37; Matthews, "Race Relations in Georgia," 300 , for facts on Ware and other schools in Georgia. House Executive Documents, 47 Cong., 1 Sess., No. 1: Report of the Secretary of the Interior (4 vols., Serials 2017-20, Washington, 1881-1883), IV, 4-307, gives statistics of secondary schools. On the place of Ware and other public schools in the life of the Augusta black community see Augusta Chronicle, July 2, 22, August 31, September 24, 1880; June 10, 24, July 17, August 5, September 16, December 31, 1894; March 3, 12, April 13, 14, June 14. August 18, 1895; August 25, October 14, 22, 1897; September 29, 1898; January 11, 13, November 16, 29, December 24, 1899; February 11, 18, March 7, 1900; Washington Bee, April 30, 1898; Savannah Tribune, April 23, 1898; Augusta Union, January 27, 1900; Haynes, Black Boy of Atlanta, 99-112; J. L. Nichols and William H. Crogman, Progress of a Race, or the Remarkable Advancement of the American Negro (Napierville, Ill., 1929), 373; German, "Queen City," 135-37. For the changing attitude of School Superintendent Lawton Bryan Evans toward the propriety of providing public high school education for blacks, compare pp. 309-11 with p. 403 of "Minutes" (1876-91).

20 Matthews, "Race Relations in Georgia," 297-98; George E. Clary, Jr., "The Founding of Paine College-A Unique Venture in Interracial Cooperation in the New South, 1882-1903" (unpublished Ed.D. dissertation, University of Georgia, 1965), 24. The quotation is from the Augusta Chronicle, June 9, 1897.

21 Both quotations are from the Atlanta People's Party Paper, November 2, 1894; for a similar appeal by Black in 1895 see Augusta Chronicle, September 26, 1895. Naturally, Black also sought Negro votes on the more conventional grounds of patronage and of putting Negroes on juries. 
the 1880s in four "disreputable structures" which had been used for hospitals during the Civil War, the black schools, despite some upgrading during the 1890 s, could not hold all the children who wished to attend. In 1897 the board owned or rented forty-one schools with an average value of $\$ 4,622$ for whites, but only twenty-two worth about $\$ 1,100$ each for blacks. As Commissioner Lawton Bryan Evans noted repeatedly in his annual reports, the primary schools each year had to turn away three hundred to a thousand Negro children for lack of seats, and more probably would have attempted to register if the board had overridden efforts, led by Joseph Ganahl, to keep tax rates low.22 Enrollment figures support Evans's statements. Although the percentage of Richmond County's six-toeighteen-year-old blacks enrolled rose from 18 percent in 1881 to 34 percent in 1897, the whites retained a comfortable lead, enrolling 47 percent in 1881 and 59 percent in 1897. Moreover, black children, who composed a slight majority of Richmond's school-age population, had half as many teachers as the whites: in 1881 there were 212 blacks age six to eighteen for every black teacher, and only 97 whites; in 1897, 151 and 76; in 1900, 171 and 71; and in 1910, 173 and 66 . And the black teachers were less well paid. In 1877 the white teachers received an average of $\$ 40$ per month to the blacks' $\$ 25$; in 1888 the range for whites was $\$ 35$ to $\$ 50$ a month, while the blacks got $\$ 20$ to $\$ 40$; in 1897 the whites averaged $\$ 43$ compared to $\$ 30$ for the Negroes; and in 1907 the figures were $\$ 50$ and $\$ 25$, respectively. ${ }^{23}$

When the fragmentary figures on the salaries paid to the teachers of each race are divided by the numbers of each race within the school ages, the degree of discrimination becomes clearer. As Table 1 shows, Richmond County spent three or four times as much on

\footnotetext{
${ }^{22}$ Ware High in 1895 was taught in a building described by the Chronicle of June 9 as "a relic of past days." The quotation in the text is from Helen Chapman, "The Contributions to Education of Lawton B. Evans"' (unpublished M.A. thesis, University of Georgia, 1949), 20. See also Augusta Chronicle, June 17, September 15, 18, October 14, 1894; January 20, September 22, 1895; Evans, Thirteenth Annual Report of the Public Schools of Richmond County, 1885 (Augusta, 1886), 16; and Evans, Fifteenth Annual Report of the Public Schools of Richmond County, 1887 (Augusta, 1888). In addition, see "Minutes" (1876-91), 235-36, 384; and "Minutes" (1900), 53-57.

22 The statistics for teachers' salaries for 1897 are incomplete, since the totals for salaries in the printed state report for 1897 do not match those computed by adding up the average salaries multiplied by the number of teachers of each "grade" by race. Apparently, the salaries of principals (who also taught) were left out of the average salary figures, for their salaries were high enough to have raised the averages above the stated 1897 figures. Since the racial differential in the principals' salaries was higher than that for other teachers, exclusion of them reduces the measured racial disparity for 1897 . It also understates the level of support per student for white schools in 1897 by perhaps $\$ 1$ to $\$ 1.50$. Figures for Table 1 come from the published reports of the Augusta school board, as well as the unpublished "Minutes" for the relevant years.
} 
TABLE 1

EXPENDITURes on TEACHERS' Salaries Per School-Age Child, Richmond County, Georgia

$\begin{array}{cccc}\text { Year } & \text { White } & \text { Black } & \begin{array}{c}\text { Ratio of White } \\ \text { to Black }\end{array} \\ 1877 & \$ 6.48 & \$ 1.66 & 3.90 \\ 1895 & 6.69 & 1.46 & 4.58 \\ 1897 & 5.14 & 1.80 & 2.86 \\ 1899 & 6.34 & 2.04 & 3.11 \\ 1900 & 6.30 & 1.84 & 3.42 \\ 1901 & 6.89 & 1.61 & 4.28 \\ 1907 & 7.72 & 1.69 & 4.57\end{array}$

each white as each black pupil, and if the figures on expenses for buildings and maintenance were available by race, the measured degree of discrimination would no doubt rise. In 1907 and 1908, for instance, the board made no physical improvements on its black schools, but completed" two new white schools valued at $\$ 85,000$ and $\$ 100,000$, respectively. Finally, despite giant strides in imparting bare literacy to Augusta teenagers, discrimination in the outputs of the school system paralleled discrimination in service levels: in 1894,5 percent of the white and 13 percent of the black youths over ten in Richmond County could not read and write; in 1898 the figures were 4 percent and 12 percent; in 1908, 0.2 percent and 2 percent. ${ }^{24}$

And though whites appear to have partially subsidized black schools in Augusta, James C. C. Black greatly exaggerated when he claimed that Negroes were educated "at the expense of the whites." Assuming that Negroes paid indirect taxes, which were levied chiefly on liquor, in proportion to their numbers, rather than their wealth, it is possible to compute the blacks' share of total taxes and fees. Column 1 of Table 2 gives the figures for the years around the turn of the century for which both tax and expenditure statistics are available. Column 2 of the table shows the proportion of teachers' salaries which went to Negroes, column 3 the resultant white "subsidy" in dollars, and column 4 the increase in the tax rate, in mills, which whites in the county had to pay because of their subsidy to black schools. It cost the average white male adult in Richmond County, who owned $\$ 3,018.89$ worth of property, only $\$ 1.42$ per year to subsidize the black schools at the height of the subsidy in

24 The reports on the cost of building the white schools come from the Georgia, Department of Education, Thirty-sixth Annual Report (Atlanta, 1907), 382; and Thirty-seventh Annual Report (Atlanta, 1908), 482; other statistics from the printed annual reports of the Richmond County Board of Education as well as the state school reports for the appropriate years. 
TABLE 2

Proportion of TAXes Paid, Expenditures on Blacks IN Richmond County, Amount of White SUBSIDY, AND INCREASE IN TAX RATE FOR WhITES Due to Black Subsidy

$\begin{array}{ccccc}\text { Percent Taxes } & \begin{array}{c}\text { Percent } \\ \text { Expenditures on } \\ \text { Blacks }\end{array} & \begin{array}{c}\text { White } \\ \text { Subsidy }\end{array} & \begin{array}{c}\text { Change in } \\ \text { White Tax Rate } \\ \text { (in mills) }\end{array} \\ 1895 & 15.2 & 19.7 & \$ 3,351 & 0.15 \\ 1897 & 14.8 & 28.0 & 10,152 & 0.47 \\ 1900 & 10.9 & 24.2 & 10,668 & 0.47 \\ 1901 & 11.4 & 20.3 & 7,407 & 0.33\end{array}$

1900 , and if statistics for buildings and maintenance existed, even this subsidy would probably disappear.

To show how the figures for column 1 , Table 2, were calculated, 1895 can be used as an example. The state appropriation to Richmond County in that year was $\$ 31,880$. This derived from indirect taxes, the lease on the state-owned railroad, and property taxes, amounting to $\$ 146,828, \$ 210,006$, and $\$ 600,000$, respectively, at the state level. It was assumed that blacks were "due" income from the lease and indirect taxes in proportion to the percentage of black adult males to all adult males (proxies for households) in the state. Blacks made up about 44.7 percent of the adult males. Thus, the blacks in Richmond County were "due" 44.7 percent of that part of the state appropriation which was made up of indirect taxes (37.3 percent), or $\$ 5,315$ from indirect taxes.

Blacks owned 3.5 percent of the taxable property in Richmond County in 1895 . Thus, they were "due" 3.5 percent of that part of the state appropriation which came from property taxes (62.7 percent) or $\$ 700$.

Poll taxes all went to schools in the county where they were collected. Richmond County blacks paid $\$ 4,121$ in poll taxes in 1895 . After the institution of the white primary in 1898 and 1899 the number of blacks who paid their poll taxes dropped off drastically, which accounts for the decline in the percentages in column 1 from 1897 to 1900 and 1901 .

Finally, blacks paid about 3.5 percent of the $\$ 45,000$ local property tax for schools, or $\$ 1,575$.

Thus, the total estimated taxes paid by blacks for schools was $\$ 11,711$, or 15.2 percent of the $\$ 31,880$ state and $\$ 45,000$ local taxes.

Black schools in 1895 actually received in salaries $\$ 12,955$, which would make the subsidy $\$ 1,244$, but, under the assumption that the 
expenses for building and maintenance were distributed proportionately to salaries-an assumption which no doubt overestimates the white subsidy-the total subsidy from whites amounted to $\$ 3,351$. The relatively small funds which the school board received from private sources and tuition have been disregarded in these calculations because of insufficient evidence about their origins.

In 1897 seventeen-year-old Ware High was thriving, having doubled the number of students and added an assistant teacher over its life span. Its principal since 1891, Henry L. Walker, had organized the Negro State Teachers' Association and served as its president for a decade and was highly regarded by both the Augusta black community and the school board. Since Ware, like the white public high schools, charged tuition, the black high school's net cost to the board in 1897 came to only $\$ 842.50$, which amounted to less than 1 percent of the board's total expenditures or approximately 5 percent of the money spent on black schools. Yet on July 10, 1897, the board, pointing to the need for more black primary schools and claiming that the schools were financially hard pressed, voted to terminate Ware and use the $\$ 842.50$ to hire four elementary teachers to teach fifty students for $\$ 25$ a month. ${ }^{25}$ Though the evidence is fragmentary, it appears likely that the initial impetus to end Ware came from Lucy Laney, the (black) principal of one of the competing private black high schools. ${ }^{26}$

Announced without previous public discussion, the board's decision aroused a storm of protest in the black community. Within five days 155 Augusta blacks signed a petition, which cited the egalitarian requirement of Section 9 of the 1872 Public Law 346 and quietly punctured the board's declaration of poverty by pointing out that the increase in funds for 1898 recently voted by the state legislature would allow the board easily to satisfy the needs for both primary and secondary schools for the blacks. ${ }^{27}$ Considerably wealthier than the average Augusta Negro, the petitioners were mostly professionals or skilled craftsmen who, despite their economic dependence on white customers or employers, were not afraid to assert their rights. ${ }^{28}$

\footnotetext{
23 Augusta Chronicle, June 17, 1897; “Minutes” (1891-99), 370-72.

26 For evidence of Laney's role in this affair, which may have been motivated by a desire to expand black primary education or may simply represent an effort to kill off the chief competitor of her private high school see the working-paper version of this paper, note 38 .

2" Since the legislature had increased its general school appropriation, Richmond County would receive 41 percent more from the state in 1898 than in 1897 . Thus, the projected total 1898 budget for Richmond County's schools would rise by $\$ 13,000$ or approximately 23 percent over the 1897 level.

2" The multiplicity of often obscure sources for my information on individual Augustans prevents their extensive citation here. I instead refer interested scholars to my previously cited working paper, which I shall be happy to supply upon request.
} 
The chief organizers of the protest, who also directed and largely financed the subsequent court case, were first cousins whose families' intertwined personal, business, and church relationships predated the Civil War. Virtually indistinguishable in surviving photographs from men classed as Caucasians, John C. Ladeveze and James S. Harper employed the wealth, education, and resultant social position which constituted the legacy of their white ancestors to become pillars of black society, and, in this case, to fight against racial discrimination. Grandsons of a white Frenchman who had lived openly with a mulatto woman in antebellum Augusta, Harper and Ladeveze were playmates in childhood and business associates as adults, as their fathers had been. Their lieutenants in the Ware movement, Joseph W. Cumming and William J. White were, like Harper and Ladeveze, very light-skinned, comparatively wealthy, and quite active in all aspects of the life of the black community. A Republican, Populist, and later Socialist, White was the single most influential figure in nineteenth-century black education in Augusta as well as editor of the most important local black newspaper. Like Cumming, whose name seems to have been listed first in the eventual court case for purely alphabetic reasons, White had a Caucasian father and appears, from his role in this and other black protest movements, to have been particularly sensitive to racial slights which came from men barely lighter in skin tone than himself.

Although agreeing to meet in special session to consider the black petition, the school board on August 28, 1897, rejected the arguments of the written document and oral presentations by Ladeveze and White and reaffirmed its decision by a vote of 23 to 3 , with two abstentions. It is significant that all three of the school board's dissenters represented the Fifth Ward, a lower-class factory area which was the strongest Populist ward in the city, that at least one of the pro-Ware board members, a former grand master workman of the Knights of Labor, Milledge M. Connor, was an active member of the People's party, and that another, Dr. James P. Smith, was widely "recognized as a true \& stanch [sic] friend of the mill people," most of whom were of the white working class. ${ }^{29}$ Although a compromise had been rumored before the meeting, the board merely offered to restore Ware when economic conditions permitted. Recognizing the hollowness of this promise, the blacks immediately brought two suits in the local Superior Court.

The Negroes chose as their lawyers three whites who had never before publicly exhibited any special sympathy for the race, but

" German, "Queen City," 92; Augusta Chronicle, July 27, 1894; May 14, 1895; July 11, 16, August 26, 29, September 23, 1897; February 19, 1900. The description of Smith is in Augusta Tribune, January 10, 1899. 
who were each, in some respect, rebels against the close-knit Augusta establishment. Born in New York, the chief counsel, Salem Dutcher, Jr., was an intellectual and a fellow-traveler with the Populists and had led an abortive crusade in 1894 against Augusta's most powerful politician. One of Dutcher's cocounsels, Hamilton Phinizy, though born to affluence and social status, was a public agnostic. The other, Joseph S. Reynolds, was a self-made man who worked as a drugstore clerk and traveling salesman to support himself while he read law. Neither Dutcher, Phinizy, nor Reynolds was then among the recognized leaders of the Augusta bar.

The briefs which these lawyers filed in the Superior Court in Cumming and a companion case, Albert S. Blodgett and Jerry $M$. Griffin v. School Board, focused directly on the equal-protection clause of the Fourteenth Amendment to the United States Constitution. For the board to continue to support the Tubman and Hephzibah high schools for whites while eliminating Ware, they contended, was simply an unconstitutional denial of equal protection. If, as the school board alleged, it lacked the means to extend black primary schools to all who desired to enroll, that condition arose from "the illegal action of said Board in appropriating to the white school population of said City largely more of the public school fund than it is legally entitled to." Their clients having exhausted the available nonjudicial remedies, counsel asked in the Blodgett case for a mandamus directing the board to reinstate Ware and in Cumming for injunctions to prevent the county tax collector from gathering that part of the school tax which went to high schools and to bar the board from spending any money on white high schools unless they also continued Ware. ${ }^{30}$

The lawyers filed two separate cases because they disagreed about the appropriate mode of action in the complicated area of the nineteenth-century "extraordinary remedies," such as writs of mandamus and injunction. Originally instituted in the English courts of equity and common law because general laws failed to do justice in particular cases, the writs circumvented the harsh principles and ponderous usages of the common-law courts. Although the prac-

30 The quotation is from George F. Edmunds's printed brief in "File Copies of Briefs, 1899," Vol. 14, Case No. 164, p. 21, in U. S. Supreme Court Library, hereinafter referred to as Supreme Court File. Other information on the local briefs is in Augusta Chronicle, September 22, 1897; and Transcript of Record No. 621, October Term, 1898, Appellate Case File No. 17206, in National Archives, Washington, D. C., referred to hereinafter as National Archives File. Since Blodgett was never considered as important a case by counsel and since the plaintiffs in that case apparently took no part in raising money or propagandizing for the cases, I have devoted less attention to them. Blodgett, a mulatto who may have been the son of white Reconstructionist Foster Blodgett, Jr., was a grocer whose son married one of John Ladeveze's sisters. Griffin was a brown-skinned barber and president of one of the town's largest benevolent societies, whose son later married one of James Harper's daughters. 
tices and procedures of law and equity courts had been gradually merged in the United States and although the "extraordinary" remedies were fast becoming more ordinary in the late nineteenth century, the writs retained something of their special character. Neither writ would be issued until the petitioners had exhausted all other possible courses of legal action, and neither would be granted in "doubtful" cases. Moreover, an injunction was purely negative, an order by a court of equity designed to prevent someone from acting. By contrast, the common-law writ of mandamus was an order to a public official to carry out some positive act, usually to do something he had refused to do, more rarely to rescind or reverse an action already taken. Of equal importance in these cases, the circumstances in which courts would issue writs of mandamus were changing in the late nineteenth century. Thus, a leading legal text of the era repeated the traditional view that "mandamus will lie to compel the performance of duties purely ministerial in their nature, when they are so clear and specific that no element of discretion is left in their performance," but it also stated that "where a discretion is abused, and made to work injustice, it may be controlled by mandamus."'31

Largely ignoring the equal-protection clause argument, school board counsel Joseph Ganahl, who had been chairman of the board's high school committee since 1876, and Frank H. Miller, a respected legal craftsman in whose offices Dutcher, Phinizy, and Reynolds had all studied law, concentrated on the question of how much discretion the board had. ${ }^{32}$ It was clear that under Section 10 of the 1872 act setting up the Richmond County schools the board could establish, maintain, or close any number of high schools, set tuition fees at any sum, hire and fire high school personnel, erect or demolish high school buildings. And in fact, in 1878 the board had dropped its subsidies to two previously semipublic high schools for

\footnotetext{
"On the development of equity law, see John N. Pomeroy, A Treatise on Equity Jurisprudence ... (San Francisco, 1907), 5-20; Owen W. Fiss, Injunctions (Mineola, N. Y., 1972), 9-11, 75-76. The quotations are from Thomas. C. Spelling, $A$ Treatise on Injunctions and Other Extraordinary Remedies (2d ed., Boston, 1901), 250, 1255. For similar treatments of mandamus see Thomas M. Cooley, A Treatise on the Constitutional Limitations . . . (6th ed., Boston, 1890), 136-37; and Forrest G. Ferris and Forrest G. Ferris, Jr., The Law of Extraordinary Remedies (St. Louis, Mo., 1926), Sections 206 and 209. Only Dutcher signed the later brief appealing Blodgett to the Georgia Supreme Court. For the disagreement on strategy between counsel see Augusta Chronicle, March 25, 1898.

s2 For biographical details on Miller see William J. Northen, Men of Mark in Georgia (7 vols., Spartanburg, S. C., 1974), IV, 33-38; Lucian L. Knight, A Standard History of Georgia and Georgians (6 vols., Chicago and New York, 1917), V, 2777-78. The ironic fact that all three lawyers for the blacks were Miller's pupils I learned from Scholes' Directory of the City of A ugusta (Augusta, 1886), 311; Augusta Chronicle, December 24, 1917; and a private letter from Mary R. Powell to author.
} 
whites, the Richmond and Summerville academies. The question was whether Section 9 of the 1872 act or the equal-protection clause limited the board's discretion in governing high schools. Arguing that Section 9 applied only to the previous sections of the act, which required the board to establish a system of primary schools, and that Section 10 on high schools granted the board absolute discretion, Ganahl and Miller contended that the board was within its rights in "temporarily" suspending Ware because of a lack of funds. Since it would have been "unwise and unconscionable to keep up a high school for sixty pupils and turn away three hundred little negroes who were asking to be taught their alphabet and to read and write," the board's actions were also equitable. Therefore, the plaintiffs' contentions had no basis in either law or equity. ${ }^{33}$

In a decision which the Chronicle termed "what most of those familiar with the law thought it must be," Superior Court judge Enoch H. Calloway, a plantation-born former state senator whose reputation as a racial moderate did not prevent his later becoming chairman of the State Democratic Executive Committee, enjoined the board but denied other relief.34 Granting the contention of Ganahl and Miller that the board had discretion to abolish all the high schools or tailor them to fit the needs of students of different races and geographical areas, Calloway contended that once the board did decide to open public high school facilities for whites, it had to offer them to blacks as well. Properly declining to rest his decision on a constitutional provision if a statutory basis was possible, Calloway argued that unless Section 9 was read as limiting the board's discretion under Section 10 the whole scheme would contravene the equal-protection clause. Therefore, solely on the basis of the statute, he enjoined the board from spending any money on white high schools without reopening Ware. Yet, since he admitted that the board could at its discretion abolish the high schools entirely and since there was some doubt whether it had sufficient funds to run the high schools, Calloway declined to issue the mandamus called for in Blodgett. And because the tax levy for high schools was not separable from that for elementary schools, it would have been "unwise," according to the judge, for the court to engender confusion by enjoining the tax collector.

Raising no new arguments in their beliefs, counsel for both the

ss See Ganahl and Miller, "Return to Rule," 16, National Archives File.

34 The quotation is from the Augusta Chronicle, December 24, 1897. For biographical details on Calloway see the Chronicle. November 11, 1894; September 29, November 3,5, 15, 1898; Augusta Herald, October 30, 1898; Allen D. Candler and Clement A. Evans, eds., Georgia (3 vols., Atlanta, Ga., 1906), I, 295-99, for more biographical details. For his opinions in Cumming and Blodgett see Augusta Chronicle, December 23, 24, 1897. 
board and the blacks appealed the decisions to the Georgia Supreme Court. Speaking for a unanimous court, Chief Justice Thomas Jefferson Simmons, a former Confederate colonel and president of the state Senate, and a leading delegate to the 1877 state constitutional convention, ruled in favor of the board. In an opinion studded with factual inaccuracies and petty technicalities, Simmons, who had gone far out of his way in an earlier case to declare constitutional the practice of refusing to spend on black schools in the town of Eatonton any money derived from local taxes on whites, overruled Calloway's construction of the 1872 act and blithely dismissed, without giving any reasons or citing any precedents, the equalprotection argument. Section 9, in Simmons's view had no effect on Section 10, which granted the board entirely unlimited discretion over high schools. Moreover, the black taxpayers had no more right to complain that they were taxed to support high schools without receiving any benefits from them than did white taxpayers who had no children currently enrolled in the public high schools. Finally, the same arguments which he cited to dissolve the injunction dictated denial of the petition for mandamus against the board. ${ }^{35} \mathrm{Al}-$ though it had expected the state Supreme Court to uphold Calloway, the Chronicle of March 25, 1898, greeted Simmons's decision as providing "the greatest good for the greatest number." "While the movers in the opposition . . . were, no doubt, impelled by a desire to maintain the interests of their race as they saw them, they will in the end see that the board has acted wisely in the matter ...." It was better to give the black masses the "bread and meat" of primary schools, the paper had stated in December 1897 than to provide the "pati de foie gras [sic]" of high schools for the Negro elite. ${ }^{36}$

Ladeveze, Harper, and their compatriots did not despair. Rather, they enlarged the scope of their fund-raising and propaganda efforts (garnering, for example, the munificent sums of $\$ 5.06$ from two churches in Savannah and $\$ 5.00$ from Booker T. Washington) and recruited as their counsel for the appeal to the United States Supreme Court one of the country's outstanding constitutional and

9s 29 S.E. 488 (1898). For biographical facts about Simmons see Augusta Chronicle, October 29, 1894. The briefs are in the Supreme Court File. Simmons's earlier dictum came in Reid v. Town of Eatonton, $80 \mathrm{Ga}$. 755, 758 (1888). In an attempt to strengthen his case against allegations of racial discrimination by the board, Simmons denied, contrary to facts stipulated by both sides, that the board had ever supported a boys' high school for whites. To buttress his contention that Section 10 was completely separate from the foregoing regulations of the free common schools, he patently misread the 1877 amendments as requiring tuition at high schools, instead of merely allowing the board discretion on whether or not to charge tuition.

36 Augusta Chronicle, January 28, March 25, 1898 (first quotation); December 24, 1897 (other quotations). 
corporation lawyers, George Franklin Edmunds. ${ }^{37}$

A United States senator from Vermont from 1866 to 1891, Edmunds was an unreconstructed Radical Republican who, along with many other Republicans of the late nineteenth century, believed that the Fourteenth Amendment was meant to protect human rights as well as those of corporations. One of the leading lawyers for the Southern Pacific Railroad in the important San Mateo and Santa Clara cases, which established the proposition that corporations were meant to be included as "persons" under the Fourteenth Amendment, and for the challengers of the federal income tax in Pollock v. Farmers' Loan and Trust, Edmunds had been one of the principal framers of the 1890 Sherman Antitrust Law as well as the $1871 \mathrm{Ku}$ Klux Klan bill and the 1875 Civil Rights Act. Indeed, it was to Edmunds that Justice John Marshall Harlan had turned for consultation when he drafted his famous dissent in the 1883 Civil Rights Cases, and Harlan's opinion in that case closely followed the arguments and even some of the phraseology of Edmunds's earlier Senate speeches in defense of the Civil Rights Act. A close adviser to Presidents Ulysses Simpson Grant and Rutherford Birchard Hayes and a serious candidate for the Republican nomination for President in 1884, Edmunds had turned down two offers of appointment to the Supreme Court. Recruited by Harper while wintering at the resort town of Aiken, South Carolina, which was only fifteen miles from Augusta, Edmunds was so touched by the blacks' plight that he took the case without fee. ${ }^{38}$ Thus, even before the founding of the National Association for the Advancement of Colored People (NAACP) in 1909, black litigants in civil rights cases were repre-

"For the fund raising see Savannah Tribune, November 5, 12, 1898; Ladeveze to Washington, June 1898; November 11, 17, 1898, in Container 142, Booker T. Washington Papers (Manuscript Division, Library of Congress, Washington, D. C.). Despite the appeal to Washington to help in the fund raising, the Augustans were forced to rely almost entirely on their own resources. For earlier fund-raising activities see Augusta Chronicle, January 14, 1898. In contrast, the NAACP received a $\$ 100,000$ grant from the liberal Garland Fund in 1929 to fight for equalization of school facilities among other things. See Kluger, Simple Justice, 132-33.

st The fact that Edmunds burned all his papers before he died probably accounts fot the lack of a published biography. Selig Adler's "The Senatorial Career of George Franklin Edmunds, 1866-1891" (unpublished Ph.D. dissertation, University of Illinois, 1934) provided most of the scanty biographical details. Other information derives from Santa Clara County v. Southern Pacific Railroad Co. 118 U.S. 394 (1886); Howard J. Graham, Everyman's Constitution: Historical Essays on the Fourteenth Amendment, the "Conspiracy Theory," and American Constitutionalism (Madison, Wis., 1968), 88n; Alan F. Westin, "John Marshall Harlan and the Constitutional Rights of Negroes: The Transformation of a Southerner," Yale Law Journal, LXVI (April 1957), 240n, and an undated note by Laura Harper in the Harper Family Papers. It is interesting to compare the devotion of Edmunds to the rights of the downtrodden with the scorn shown by a leading twentiethcentury corporation lawyer, John W. Davis, on whom see William H. Harbaugh's Lawyer's Lawyer: The Life of John W. Davis (New York, 1973). 
sented by well-qualified-in this case, superlative-counsel. The Supreme Court's repeated rulings against Negroes in this period did not, with one exception, result from inadequate lawyers. ${ }^{39}$

In what may have been a tactical error, Edmunds decided to appeal only Cumming, on which there was a full record of depositions, briefs, and decisions, but to let Blodgett go. Since Chief Justice Simmons had not bothered to file a full opinion in Blodgett, it was unclear on the face of the decision whether a "substantial federal question" was involved. Probably more important, the Georgia Supreme Court had ruled that the 1872 statute granted the board complete discretion in governing high schools, and a mandamus, at least according to the traditional view, could not control a discretionary act. Since the federal courts would not overturn the highest state court's construction of its state's laws, the question of discretion must have seemed muddled, at the very least. Confident that he had a winnable case, Edmunds may have thought that the Cumming case raised the issues sufficiently that the question of the form of remedy made little difference. ${ }^{40}$ And there was good reason for that confidence.

Though the Supreme Court had never before ruled on racial discrimination in education per se, its previous Fourteenth Amendment decisions seemed to support the position of Edmunds's clients. The Court had been willing to intervene to protect railroads and Chinese laundrymen from "arbitrary classifications" or discriminatory actions of legislative, executive, or judicial officers of the states and to launch independent investigations to determine whether in fact the discretion allowed by various statutes had been employed in an "unjust" or "unethical" manner. Despite its negative phraseology, the equal-protection clause had been held to provide blacks with a "positive immunity" against legal discrimina-

32 The attorney general or solicitor general appeared for the blacks in U.S. v. Reese et al. (92 U.S. 214); U.S. v. Cruikshank (92 U.S. 542); Strauder v. West Virginia (100 U.S. 303); Ex parte Virginia (100 U.S. 339); Ex parte Siebold (100 U.S. 371); U.S. v. Harris (106 U.S. 629); Ex parte Yarbrough (110 U.S. 651); The Civil Rights Cases (109 U.S. 3); and James v. Bowman (190 U.S. 127). In Plessy the chief lawyer was the respected "Judge" Albion Tourgée; in the 1903 Alabama disfranchisement cases, Giles v. Harris (189 U.S. 475) and Giles v. Teasley (193 U.S. 146), black lawyer Wilford H. Smith filed competent briefs; and in the 1904 Virginia disfranchisement cases of Jones v. Montague (194 U.S. 147) and Selden v. Montague (194 U.S. 153) the blacks were represented by John Sergeant Wise, an excellent lawyer who practiced on Wall Street as well as in Virginia. The exception referred to was Cornelius J. Jones, a blustering black Vicksburg attorney, whose failure to present the disfranchisement case of Williams v. Mississippi (170 U.S. 213) correctly allowed the Court easily to sidestep the crucial precedent. For his bluster see the file on Williams v. Mississippi in the National Archives.

40 Edmunds's confidence is reflected in his correspondence with the Supreme Court (National Archives File) and in a letter from Ladeveze to Booker T. Washington, November 11, 1898, in Container 142, Washington Papers. 
tions which "lessen[ed] the security of their rights which others enjoy." Moreover, the Plessy case, on which Ganahl and Miller put so much emphasis, actually allowed racial distinctions only if the accommodations on segregated railway cars were equal. Even if the segregation of school children was constitutional-and Edmunds did not challenge it directly in his brief-the opportunities offered students of each race had to be substantially the same, if the court followed the "equal, but separate" rule of Plessy. Abolishing Ware was, Edmunds charged, an "arbitrary denial of the equal protection of the law," not an action which the Fourteenth Amendment left to the discretion of the school board."1

While Edmunds did not examine state and federal district court opinions on school discrimination, the vast majority of previous decisions in both southern and northern courts favored his views, and his failure to discuss them was probably a mistake. The leading federal cases were $U$. S. v. Buntin and Claybrook v. Owensboro. In Buntin Judge John Baxter instructed a federal jury that it did not have to grant the petition of a black child who wished to enter a white school as long as the segregated school provided by the states offered "substantially the same facilities and educational advantages that were offered in the school established for the white children . . . .' In Claybrook Judge John Watson Barr, a friend of Justice Harlan's, declared unconstitutional a Kentucky statute which set up a racially segregated local taxation and expenditure system for schools in Owensboro, Kentucky. The equal-protection clause, Barr asserted, "can only mean that the laws of the states must be equal in their benefit, as well as equal in their burdens ... .," and while absolute equality was "impracticable," the distribution had to be made "upon some fair and equal classification or basis." 12 State court decisions from Arkansas, California, Kentucky, New York, and North Carolina all upheld the view that the equal-protection clause guaranteed "equal benefits" or "equal advantages." 43 Summarizing state and federal cases on the subject

${ }^{11}$ Quotations are from Edmunds's printed brief, 12-15, in Supreme Court File, citing Chicago, Burlington and Quincy Railroad Co. v. Chicago, (166 U.S. 226); Gulf, Colorado, and Santa Fe Railroad Company v. Ellis(165 U.S. 150); Yick Wo v. Hopkins (118 U.S. 356); Strauder v. West Virginia (100 U.S. 303); and Plessy v. Ferguson (163 U.S. 537). In his opinion in Cumming Harlan implied that at the oral argument Edmunds had challenged school segregation per se. The Court, however, declined to rule on that question on the stated grounds that the legality of segregation had been conceded in the lower courts and in the briefs.

${ }^{42} U$. S. v. Buntin, 10 F. 730, 735 (1882); Claybrook v. Owensboro, 16 F. 297, 302 (1883).

49 Maddox v. Neal, 45 Ark. 121 (1885); Ward v. Flood, 48 Cal. 36 (1874); Dawson v. Lee, 83 Ky. 49 (1885); People ex. rel. King v. Gallagher, 93 N.Y. 438 (1883); Puitt v. Gaston County Commissioners, 94 N.C. 709 (1885). For discussions of these and similar cases see Gilbert T. Stephenson, Race Distinctions in American Law (New York, 1910), 196-99; 
in the 1891 edition of his General Principles of Constitutional Law, Judge Thomas McIntyre Cooley, the leading legal commentator of the day, declared school segregation constitutional only if "the schools are equal in advantages, and the same measure of privilege and opportunity is afforded in each." 44 To rule against the black appellants in Cumming, therefore, the Supreme Court would have to set its face against a line of precedent firmly established in the lower courts.

Yet in a deeper, less strictly logical sense the trend of Supreme Court decisions was unfavorable to the blacks' cause. The overwhelming fact was that the Court had rarely been willing to act or even to allow Congress to act to protect blacks against the assaults of the states or individuals. The Slaughter-House Cases had narrowed the scope of the privileges and immunities of $U$. S. citizens so much that the clause of the Fourteenth Amendment became nearly meaningless; Reese, Cruikshank, Harris, and Williams had undermined federal protection of voting rights; the Civil Rights Cases had outlawed federal power to prohibit racial discrimination in most commercial transactions by a very strict definition of "state action"; Plessy had ruled segregation constitutional."5 Moreover, at the same time that it stripped Negro rights of the Fourteenth Amendment's protections the Court had increasingly employed it to restrict congressional and state legislative efforts to control the economy. Committed to the difficult and controversial task of judicial oversight of the regulation of businesses, the Court must have hesitated to get involved in reviewing decisions of school boards, too. Suppose the Supreme Court granted the injunction and the school board complied by erecting a new building in which to house the black high school. Then, Ganahl suggested in his brief, could not the Negroes demand that the local court ensure that the black and white schools were entirely equal in facilities brick by brick, in staff salary by salary, and in other respects? Would not such a situation inextricably intertwine the courts in matters better left to "political" bodies such as the school board, whose actions could be

Charles S. Mangum, Jr., The Legal Status of the Negro (Chapel Hill, N. C., 1940), 89-91, 126-31; Maurice L. Risen, Legal Aspects of Separation of Races in the Public Schools (Philadelphia, 1935), 48-51, 70-84.

" Cooley, The General Principles of Constitutional Law in United States of America (2d ed., Boston, 1891), 242; and similarly, Cooley's $A$ Treatise on the Law of Torts, or the Wrongs Which Arise Independent of Contract (2d ed., Chicago, 1888), 338-39, which was still the current edition of this book in 1899.

4s The Slaughter-House Cases, 83 U.S. (16 Wall.) 36 (1873). For citations to the other cases, see note 39 above. There are good discussions of these cases (but a misleading treatment of Cumming) in Robert J. Harris, The Quest for Equality: The Constitution, Congress and the Supreme Court (Baton Rouge, La., 1960), 57-109. 
reviewed directly by the voters? Should the courts intervene in a case where it was doubtful whether a high school for sixty pupils served the interests of blacks better than elementary classes for two hundred? Even granting all these points, Miller and Ganahl continued, wasn't it necessary for the appellants to show bad faith on the part of the board to be able to claim a remedy at equity? Since "no evil eye or combination is averred or shown against the Board of Education," should the courts step in to reverse what was at most "an error of judgment," not an act directed at the blacks "on account of" their race?46

The indifference to Negro rights of most of the justices who faced these questions on the United States Supreme Court is too well known to require comment. But what of John Marshall Harlan, whose caustic, lonely dissents in Civil Rights, Plessy, and other cases have led prominent scholars to describe him as a man with "a messianic commitment to Negro rights," who gave "undeviating support to Negro civil rights" on the bench?"7 That a former slaveholder and staunch antebellum defender of the Dred Scott decision, who before 1868 bitterly denounced the Thirteenth and Fourteenth Amendments and Negro suffrage should become a more faithful defender of black rights than any of his northern colleagues on the Court has lent a certain air of romance to his career and intrigued historians attracted by paradoxes and Pauline ideological conversions. ${ }^{48}$ And in addition to his generally pro-Negro judicial stance, Harlan had a special reason to look favorably on the appellants'

46 Ganahl brief, 8, 12, 17, Supreme Court File; Miller brief, 14, 20, ibid.

47 The quotations are, respectively, from White, American Judicial Tradition, 133; and Westin, "John Marshall Harlan and the Constitutional Rights of Negroes," 697; Similarly, see Lewis I. Maddocks, "Justice John Marshall Harlan: Defender of Individual Rights" (unpublished Ph.D. dissertation, Ohio State University, 1959), 108; Westin, An Autobiography of the Supreme Court (New York and London, 1963), 118; Florian Bartosic, "The Constitution, Civil Liberties, and John Marshall Harlan," Kentucky Law Journal, XLVI (Spring 1958), 446. For a more careful and qualified opinion see Louis Filler, "John M. Harlan," in Leon Friedman and Fred L. Israel, eds., The Justices of the United States Supreme Court 1789-1969: Their Lives and Major Opinions (4 vols., New York and London, 1969), II, 1281-95.

" Maddocks, "Justice John Marshall Harlan," 1-47; David G. Farrelly, "Harlan's Formative Period: The Years Before the War," Kentucky Law Journal, XLVI (Spring 1958), 367-406; Ellwood W. Lewis, "Document: The Appointment of Mr. Justice Harlan," Indiana Law Review, XXIX (Fall 1953), 46-74; Westin, "John Marshall Harlan and the Constitutional Rights of Negroes" 658-69; E. Bruce Thompson, "The Bristow Presidential Boom of 1876," Mississippi Valley Historical Review, XXXII (June 1945), 3-30. The only published biographies of Harlan, those of Floyd B. Clark, The Constitutional Doctrines of Justice Harlan (Baltimore, 1915), and Frank B. Latham, The Great Dissenter: John Marshall Harlan, 1833-1911 (New York, 1970), add no important details. Woodward, American Counterpoint, 224; White, American Judicial Tradition, 131-33, 138-43; and Westin, "John Marshall Harlan and the Constitutional Rights of Negroes," 698, are attracted by the paradoxes of Harlan. Westin particularly emphasizes his alleged "conversion" on blackrights issues in 1868 . 
case in Cumming. As Republican gubernatorial candidate in Kentucky in 1871 Harlan had made equal education for all whites one of hìs main themes. Nominated again in 1875, Harlan extended his call for equality across racial lines, announcing at every speech in his extensive canvass his belief in equalizing state school expenditures for blacks and whites. "The education of the colored children of the Commonwealth is a matter of the profoundest concern to every right-hearted, liberal-minded citizen," candidate Harlan announced in one typical debate with his 1875 Democratic opponent. "There is no question of graver moment presented for our consideration." Approvingly, he quoted the 1875 state Republican platform's statement on the issue: “. . . as a measure of justice, no less than wise statesmanship, we hold that the provision now made for the education of colored children shall be increased until they are afforded, in their separate schools, facilities for obtaining instruction in every respect equal to those provided for white children." 49 Thus, the issues raised by Cumming were hardly new to Harlan. Fuily aware of the importance of public education in providing equal opportunities to poor whites and blacks, Harlan had twenty-four years earlier committed himself wholeheartedly to equal expenditure regardless of race or the amount of taxes paid.

Yet in his opinion for the Court Harlan almost casually accepted the arguments and statements of fact of Miller and Ganahl. Citing no previous cases from either state or federal courts, the justice circumvented the question of whether Plessy required equal privileges by simply not discussing it. Predicting ingenuously that the school board would respond to an injunction by closing the white high schools instead of by reopening Ware, Harlan concluded that the proposed injunctive remedy would damage white children without assisting blacks. ${ }^{50}$ Ignoring the fact that mandamus had rarely been held to control discretionary acts and seemingly unaware of the existence of the Blodgett case, Harlan suggested that if the blacks had sought an order compelling the board to reopen Ware, "different questions might have arisen in the state court." ${ }_{51}$

49 The Democratic platform was silent on the issue, and gubernatorial candidate James B. McCreary opposed taxing whites to pay for black schools. For the speech see Louisville Courier-Journal, July 5, 1875. During the campaign Harlan did constantly condemn "mixed schools" and the public-accommodations sections of the 1875 Civil Rights Act, which he later defended in his Civil Rights Cases dissent.

so Everyone appears to have assumed from the first that the board, if enjoined, would reestablish Ware, and Ganahl's brief, 15-16, Supreme Court File, conceded as much.

${ }^{51}$ Although the printed record of Cumming, 46, Supreme Court File, did refer to "the mandamus case," Blodgett was nowhere stressed. If such considerations had occurred to Harlan early enough, of course, he might have satisfied them at the oral argument, but since no record of that argument survives, we cannot determine whether Harlan misstated the facts 
But Harlan went beyond all previous cases in acceding to the argument of the board lawyers that the blacks to sustain an equalprotection claim had to demonstrate "that the Board proceeded in bad faith . . . ," that the allegedly discriminatory action was motivated by "hostility to the colored population because of their race." And he qualified his acknowledgment that "all admit that the benefits and burdens of public taxation must be shared by citizens without discrimination against any class" by adding the words "on account of their race," and implicitly transferred the burden of proof on the question of motivation from the board to the blacks.

Unlike the Fifteenth Amendment, which prohibited denial of the suffrage "on account of race" (and therefore seemingly not on account of property, literacy, or other correlates of race), the Fourteenth Amendment stated its guarantee of nondiscrimination without qualification. "No State shall," the Fourteenth Amendment commanded, ". . . deny to any person within its jurisdiction the equal protection of the laws." The wording implies that not only could there be no discrimination because of race but also that the denial of equal treatment for any reason was unlawful, that no subterfuge for racial discrimination would pass constitutional muster. Harlan's judicial amendment of the Constitution, interpreted in light of the circumstances in Cumming, meant that it would not be possible for a Negro to prove discrimination by demonstrating that whites got a disproportionate share of public benefits. Instead, states could blatantly deny blacks equal protection so long as there was no direct evidence that they did so because of race. Yet, what other rationale could have underlain the board's decisions (detailed in Edmund's brief) to provide sufficient elementary schools for whites but not blacks, to pay substantially higher salaries to white than black teachers, to close Ware while continuing two white high schools? If, as Harlan's statement implied, a public body could evade the Fourteenth Amendment's requirements by dissimulating about its reasons for acting sufficiently to demonstrate to a southern state court that there was some other rational basis for its behavior, and if, to overcome this defense, the blacks had to show positively that it was race and race alone which led to the public body's move, then the promise of equal protection became only a derisive taunt. ${ }^{52}$

of the state court case-the blacks had, indeed, asked for a mandamus-deliberately or by mistake.

"All quotations are from 175 U.S. 544-45; on the "racial hostility" test, see E.J.R. "Legality of Race Segregation in Educational Institutions," University of Pennsylvania Law Review, LXXXII (December 1933), 157-64. 
What accounts for Harlan's opinion? Why did he not dissent in Cumming as he had so sharply and memorably in Civil Rights and Plessy, thereby laying the groundwork for some future court to reverse its racist direction? Though his voluminous papers at the Library of Congress and the University of Louisville Law School contain no information on Cumming and shed little light on Harlan's attitude toward Negro rights, scholars have offered several explanations for his decision. Some, focusing on his unwillingness to rule on the segregation question, merely note his strict construction of the judicial practice of refusing to decide matters which have not been fully argued and ignore or minimize the overall inconsistency of Cumming with Harlan's opinions in other cases on black equality. ${ }^{53}$ Concentrating too narrowly on segregation, which is merely one form of racial discrimination, they appear to underestimate how much difference it might have made in the lives of black people in America if the court had enforced equal benefits even if the services were segregated.

A second group has tried to explain the inconsistency by suggesting, without bothering to examine the full record of the case, that the lawyers for the blacks had not placed sufficient emphasis on the equal-protection clause or "clumsily presented" the issues. ${ }^{54}$ While Edmunds did make the tactical mistakes of not appealing Blodgett and not discussing lower court decisions, it seems very unlikely that these errors determined the result, for his brief presented the essential inequity and unconstitutionality of the situation clearly and in sufficient detail for the Court, acting within the relatively loose constraints of equity principles, to have decided in his clients' favor had it so desired.

A third attempt to explain Harlan's stance suggests that the justice was moved by the facts that closing Ware allowed the board to increase the opportunities for black elementary students and that former Ware students could attend private high schools with no increase in tuition. But, as Edmunds's brief pointed out, the board could have met the demand for more places in the black elementary

5s Albert P. Blaustein and Clarence C. Ferguson, Jr., Desegregation and the Law: The Meaning and Effect of the School Segregation Cases (New Brunswick, N. J., 1957), 100; Loren Miller, The Petitioners: The Story of the Supreme Court of the United States and the Negro (New York, 1966), 213-14; Westin, "John Marshall Harlan and the Constitutional Rights of Negroes," 689.

${ }_{54}$ Derrick A. Bell, Jr., Race, Racism, and American Law (Boston and Toronto, 1973), 449-51; Clark Spurlock, Education and the Supreme Court (Urbana, IIl., 1955), 181-84 (quotation on p. 183); Monte Canfield, Jr., “" 'Our Constitution Is Color-Blind': Mr. Justice Harlan and Modern Problems of Civil Rights," University of Missouri at Kansas City Law Review, XXXII (Summer 1964), 311-12; Maddocks, "Justice John Marshall Harlan," 98; Kluger, Simple Justice, 121. 
schools by the constitutionally preferable means of raising the tax rate or diverting funds from the comparatively affluent white schools. The presence of private high schools, as Edmunds also noted, was irrelevant to the constitutional question of equality in public services. ${ }^{55}$

A fourth view is that in Cumming "Harlan was probably continuing a subtle war against segregation legislation . . . ," undermining the "separate but equal" standard by denying the Court's right to look into most exercises of state "police power," thereby showing that the Court could never guarantee equality in racially separate institutions and implying that the only way to fulfill the goal of the equal-protection clause was to end segregation. This overrefined apologetic ignores Harlan's stout defense of segregated schools in Kentucky during the 1870s. Since the Court took no cases from 1877 to 1911 in which the issue of public school integration could not be sidestepped and since his private papers contain nothing bearing directly on the problem, there is simply no evidence that Harlan changed his mind on school integration after he went on the Court. ${ }^{56}$

A fifth line of argument would simply downplay the importance of the case. Perhaps Harlan just did not spend very much time thinking about it, did not realize how much more important it was to the vast majority of Negroes that they have adequate educational opportunities than that they ride in a "first-class" car on a railroad. Perhaps he was ignorant of the rapidly growing gulf between expenditures for black and white schools in the South. But Harlan had certainly long been aware of the problem of racial discrimination in education and believed in the centrality of equalizing educational opportunities during his gubernatorial campaigns of 1871 and 1875 . And, as chief judge on the Sixth Circuit Court after February 1896 he must have known of the continuing efforts by his home state to deny blacks equal schools. ${ }^{57}$ Even if he had forgotten what he had said two decades earlier and failed to observe widely known facts, why would he have bothered to erect such a high barrier to further

ss Loren P. Beth, "Justice Harlan and the Uses of Dissent," American Political Science Review, XLIX (December 1955), 1091-92; Edmunds's brief, 11-12, Supreme Court File.

${ }^{56}$ Edward H. Hobbs, "Negro Education and the Equal Protection for the Laws," Journal of Politics, XIV (August 1952), 495-97 (quotation on p. 496). Harlan could have dealt with public school segregation in Plessy or in the 1908 case of Berea College v. Commonwealth of Kentucky, 211 U.S. 45, but chose not to do so.

${ }^{57}$ On the extensive litigation of such questions in Kentucky see Stephenson, Race Distinctions, 196-98; Mangum, Legal Status of the Negro, 120-25. The 1896 case of Davenport v. Cloverport, 72 F. 689, decided by Harlan's friend Judge John W. Barr, raised issues very similar to Cumming. In the 1898 case of Henderson Bridge Co. v. Henderson City, 173 U.S. 592, Harlan's opinion for the Court cited an earlier state court case dealing with the same issues, Marshall v. Donovan, 73 Ky. 681 (1874). 
challenges to discrimination if he merely thought this a minor case rather than a crucial precedent in a key area of the law?

Nor will an explanation drawing on Harlan's judicial habits or general philosophy shed much light on Cumming. Customarily straightforward in logic, he was impatient with legal casuistry, accusing the majority in the Civil Rights Cases, for instance, of undermining the Fourteenth Amendment through "a subtle and ingenious verbal criticism." Yet his assumption that the board would close the white schools rather than reopen Ware was casuistical in the extreme, and his "racial hostility" test for equal protection was just the sort of outright judicial amending of the Constitution for which Harlan often berated his colleagues on the bench. ${ }^{58}$ An ardent nationalist who generally opposed state economic regulation as well as state infringements on noneconomic rights, Harlan in this case exalted states' rights at the expense of enforcement by the federal courts of constitutional guarantees. ${ }^{59}$ Unconstrained by such sophisticated theories as legal realism, which might have led him to defer to legislatures or cautioned him against projecting his own policy predilections into the Constitution, Harlan loosely followed a model of judging which, in G. Edward White's words, "was primarily designed to implement his individual convictions. It placed a premium on arriving at desirable results, not on internal consistency." 60

But these observations merely complicate the Cumming puzzle, for if "intuition" was Harlan's chief guide, and satisfaction of his policy ends his only thread of consistency, one is left with the view that Harlan simply desired the result in Cumming, that while he was eager to defend the largely symbolic exercises of their rights by the few turn-of-the-century blacks who could afford to attend integrated colleges, to patronize integrated theaters or hotels, or to buy first-class railway tickets, he was either blind to the much more practical problem, which directly affected much larger numbers of Negroes, of obtaining a decent education, or he opposed, at this time in his career at least, granting equal public services to blacks.

Whatever Harlan's motives, the results of Cumming were very clear. The case gave the southern and other states a green light to heighten discrimination in publicly funded activities and dis-

\footnotetext{
ss Civil Rights Cases, 109 U.S. 3, 26 (1883); Henry J. Abraham, "John Marshall Harlan: The Justice and the Man," Kentucky Law Journal, XLVI (Spring 1958), 450. For an example of Harlan's criticism of his colleagues' amendment of the Constitution by judicial decree see his bitter dissent in Pollock v. Farmers' Loan and Trust Company, 158 U.S. 601 (1895).

59 For Harlan's nationalistic views on economic matters see Mary Porter, "John Marshall Harlan and the Laissez-Faire Court (1877-1910)" (unpublished Ph.D. dissertation, University of Chicago, 1971).

so White, American Judicial Tradition, 130.
} 
couraged black litigants from seeking redress in the federal courts. After all, if the court would not overturn a system which flatly denied to blacks a service which it offered to whites, it surely would not intervene to adjust mere discrepancies in teachers' salaries, school and other facilities, and the like. In addition, the burgeoning disfranchisement movement and the refusal of the courts to block that practical nullification of the Fifteenth Amendment meant that blacks would be unable to employ the ballot box to put pressure on white officials for equal treatment.

The consequences of Cumming were nowhere more apparent than in Augusta, where to accommodate a continuing stream of students cheaply, the black elementary schools were put on double sessions in 1898, despite which a thousand black children were still unable to obtain seats in schools as late as 1910; and where the "temporary" suspension of the public high school for blacks was continued until 1937.61 Augusta also witnessed a dramatic collapse of the limited political power blacks had enjoyed since Reconstruction. A white primary eliminated blacks from municipal politics in 1899; a murder and lynching led to the absolute segregation of streetcars in 1900. The blacks' optimism was gone. As one previously hopeful black spokesman, Silas Xavier Floyd, commented, "Many say that the relations between the two races, hitherto so pleasant in Augusta, are now strained forever and that the breach can never be healed." 62 Their rights no longer protected, the four light-skinned Negroes who had initiated the case responded variously. William J. White never quit protesting but was nearly lynched for his part in organizing a statewide movement against a disfranchisement law and for his denunciation of the infamous 1906 Atlanta race riots. James Harper remained in Augusta, continuing his business and religious activities and apparently refraining from more active dissent, but one of his sons moved to Chicago where he later became a militant editor of the influential black newspaper, the Daily Defender. John Ladeveze, who according to family tradition was despondent over the outcome of the case, moved to Los

61 "Minutes" (1891-99), 435; "Minutes" (1900), 61; W. E. Burghardt Du Bois and Augustus G. Dill, eds., The Common School and the Negro American (Atlanta, 1911), 63; Range, Rise and Progress of Negro Colleges, 181. It was 1945 before a full four-year public high school, which was what Ware had been, was reestablished, according to the annual reports of the Georgia State Department of Education.

${ }^{62}$ Augusta Chronicle, November 13, 17, December 7, 1899; May 15-17, 20-21, 25, 1900. The Floyd quotation appears in the May 21, 1900, issue. The lynching was in stark contrast to a similar experience in 1895 , when the local militia had been called out to maintain law and order, and Joseph Rucker Lamar, a leading local lawyer who later became justice on both the Supreme Court of Georgia and of the United States, was appointed special counsel for the black accused of murder and defended his penniless client with considerable vigor. 
Angeles in 1900, passed over the racial barrier, and became a wellto-do real estate and insurance broker. Joseph W. Cumming stayed in Augusta until 1913 or 1914 , when he migrated to Philadelphia, passed for white, and also sold real estate. ${ }^{63}$ When even Justice Harlan reneged on the Reconstruction Amendments' promise of federal guarantees of black rights, the only safe way to obtain those rights was to cease to be a southern Negro.

${ }^{63}$ Harper Family Papers; correspondence between Mrs. Emile Veze of Arcadia, California, and author; city directories of Los Angeles, 1900 to 1930, and Philadelphia, 1915 to 1930. 